\title{
Paleobiology
}

(ISSN 0094-8373)

\section{Volume 38}

Winter, 2012

\section{CONTENTS}

\section{Feature Article}

Morphological convergence of the prey-killing arsenal of sabertooth predators

Julie A. Meachen-Samuels

Articles

Regional-scale spatial heterogeneity in the late Paleocene paratropical forests of the U.S. Gulf Coast

Phillip E. Jardine, Guy J. Harrington, and Thomas A. Stidham

Evolutionary and ecological implications of trematode parasitism of modern and fossil northern Adriatic bivalves John Warren Huntley and Daniele Scarponi

Evaluating fish scale preservation in sediment records from the oxygen minimum zone off Peru

Renato Salvatteci, David B. Field, Timothy Baumgartner, Vicente Ferreira, and Dimitri Gutierrez

Using striated tooth marks on bone to predict body size in theropod dinosaurs: a model based on feeding observations of Varanus komodoensis, the Komodo monitor

Domenic C. D'Amore and Robert J. Blumenschine

Ecological correlates of ghost lineages in ruminants

Juan L. Cantalapiedra, Manuel Hernández Fernández, Gema M. Alcalde, Beatriz Azanza, Daniel DeMiguel, and Jorge Morales

Quantifying historical trends in the completeness of the fossil record and the contributing factors: an example using Aves

Daniel T. Ksepka and Clint. A. Boyd

Problems with using rock outcrop area as a paleontological sampling proxy: rock outcrop and exposure area compared with coastal proximity, topography, land use, and lithology

Alexander M. Dunhill

Pacman profiling: a simple procedure to identify stratigraphic outliers in high-density deepsea microfossil data

David Lazarus, Manuel Weinkauf, and Patrick Diver

Climatic forcing of Quaternary deep-sea benthic communities in the North Pacific Ocean

Moriaki Yasuhara, Gene Hunt, Thomas M. Cronin, Natsumi Hokanishi,

Hodaka Kawahata, Akira Tsujimoto, and Miho Ishitake 
Electronic submission (PDF format) is requested: paleobiology@flmnh.ufl.edu

If electronic submission is not possible, send manuscripts to:

Courier Address:

Florida Museum of Natural History

Museum Road

University of Florida

Gainesville, FL 32611-7800
Mailing Address:

Florida Museum of Natural History University of Florida

P.O. Box 117800

Gainesville, FL 32611-7800

You can view and download Paleobiology from the world wide web in four places. Volumes 1-25 are at http:/ / www.jstor.org. (PDF only; requires library subscription to ecology journals within JSTOR.) Current issues back to volume 26(1) are at http://www.bioone.org/ (with a library subscription to BioOne), and at http://www.psjournals.org. Titles and abstracts back to volume 22 are free at http:/ / allenpress.com.

EDITORS:

Associate Editors: $2011 \quad$ Felisa A. Smith, University of New Mexico

2012 Thomas Olszewski, Texas A \& M Universtiy

DAvid L. Fox, University of Minnesota

MARK D. UHEN, George Mason University

JenNifer McElwain, University College Dublin

MARTIN AbERHAN, Museum für Naturkunde Berlin

WolfGANG KIESSLING, Museum für Naturkunde Berlin

2013 LINDA IvANY, Syracuse University

JAMES CRAMPTON, GNS Science

KeVIN BOYCE, University of Chicago

Peter J. WAGNER, Smithsonian Institution

JASON HEAD, University of Nebraska

Assistant EdITOR:

NATASHa AtKins

Managing Assistant Editor: Luz Helena Oviedo

FOUNDING EDITORS:

Thomas J. M. Schope AND RALPH G. Johnson
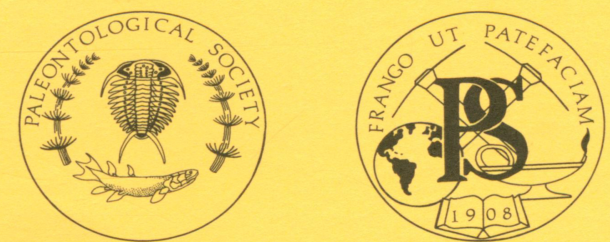

PALEOBIOLOGY (ISSN 0094-8373) is published quarterly by The Paleontological Society, 810 East 10 th St., Lawrence, KS 66044, USA. Periodicals postage paid at Lawrence, KS. POSTMASTER: Send address changes to PALEOBIOLOGY, P.O. Box 1897, 810 East 10 th St., Lawrence, KS 66044-8897, USA.

PALEOBIOLOGY is printed offset by Allen Press, Inc., Lawrence, KS 66044.

(2) This paper meets the requirements of ANSI/NISO Z39.48-1992 (Permanence of Paper). 
The Paleontological Society gratefully acknowledges Patrons of Paleobiology for 2012.

The Patrons Fund was established to broaden the basis of financial support for Paleobiology and thus to encourage paleontological publication.

$\$ 50.00$ to $\$ 100.00$, at the discretion of the Contributor

For you, or your institution, to become a Patron, send a check payable to Paleobiology to:

Paleobiology Patrons Fund

P.O. Box 1897

810 East 10th Street

Lawrence, KS 66044-8897

\section{Paleobiology Patrons}

RICHARD P. ALVORD

CATHERINE BADGLEY

RICHARD K. BAMBACH

William A. Clemens JR.

Paulo Custodi

William A. DiMichele

ROBERT M. FINKS

KARL W. FLESSA

Michael J. FoOte

ROBERT A. GASTALDO

JOHN C. HANDLEY

ANDREW B. HECKERT

JOHN R. HORNER

AUGUST ILG

JEREMY B. C. JACKSON

Michal KOWALEWSKI

WANN LANGSTON JR.

DAVID R. LINDBERG

ERNEST L. LUNDELIUS JR.

BRUCE J. MACFADDEN

HARUYOSHI MAEDA

STEPHEN W. MARLEY

GeORGE R. MCGHEE JR.

FRANK K. MCKINNEY

DAVID L. MEYER

ARNOLD I. MILLER

MICHAEL MONTENARI

KEVIN PADIAN

RANDY R. PATRICK

BRUCE RUNNEGAR

LOU ElLa R. SAUl

IN MEMORY OF TOM SCHOPF

Elizabeth C. SEASTRUM

JACEK K. SULANOWSKI

SHERMAN SUTER

JOHN M. TATE

ROgER D. H. THOMAS

BRUCE H. TIFFNEY

UNIVERSITY OF CALIFORNIA MUSEUM OF

PALEONTOLOGY

JAMES W. VALENTINE

RON F. WASZCZAK

PETER WILF 